\title{
Iono-molecular Separation with Composite Membranes VIII. Recuperative aluminium ions separation on capilary Polypropylene S-EPDM composite membranes
}

\author{
ION MARIUS NAFLIU ${ }^{1}$, HUSSAM NADUM ABDALRAHEEM AL-ANII, ${ }^{1,2}$, ALEXANDRA RALUCA GROSU (MIRON) ${ }^{1 *}$, \\ PAUL CONSTANTIN ALBU ${ }^{3}$, GHEORGHE NECHIFOR ${ }^{1 *}$ \\ 1Politehnica University of Bucharest, Faculty of Applied Chemistry and Material Science, Analytical Chemistry and Environmental \\ Engineering Department, 1-7 Gheorghe Polizu Str., 011061, Bucharest, Romania \\ Institute of Technology- Baghdad, Middle Technical University, Baghdad, Iraq \\ ${ }^{3}$ IFIN Horia Hulubei, Radioisotopes and Radiation Metrology Department (DRMR), 30 Reactorului Str., 077125, Magurele, \\ Romania
}

Environmental problems occurring in isolated or hardly accessible inhabited areas can be adequately addressed using membranes and membrane processes.In the present paper, the recuperative separation of aluminum ion from the aluminum sulfate-treated water through permeation using capillary composite membranes, from polypropylene with ethylene propylene diene terpolymer sulfonic acid (PP / S-EPDM) inclusions is followed by the reaction of complexation with 8-hydroxy quinoline. The installation used for studying the permeation process provides a usable surface area of $1 \mathrm{~m}^{2}$, the source phase solution volume is $3 \mathrm{~L}$, and the receiving phase is $300 \mathrm{~mL}$. The two phases are recirculated through the outside of the membranes (SP) and respectively through membranes $(R P)$, by means of individual peristaltic pump that can provide flow variations between 2 and $200 \mathrm{~mL} / \mathrm{min}$ by varying the intensity of the power supply. The optimal operating parameters were determined: operating time, $\mathrm{pH}$ and receiving phase flow, thus achieving an ionic flux (IR) above $10^{-11} \mathrm{~mol} / \mathrm{cm}^{2}$. s and a recovery factor (RF) over $90 \%$.

Keywords: composite membranes, EPDM, pertraction, aluminum separation, 8-hydroxy quinoline

Membranes and membrane processes have stepped in the industrial application field for almost half a century: desalination, potable water treatment and purification, hydrometallurgy, biotechnology, food industry and agriculture, fullydemonstrating their selectivity, productivity, robustness and simplicity in operation, reduced investment and competitive costs [1-3].

In the last decade, research in this area is called to solve some complex environmental issues from isolated or hardly accessible areas such as depressions [4-6], but also to increase the membrane and membrane processes selectivity, while improving the ratio between useful surface and membrane module volume [7,8].

Whether we are talking about the removal of microparticles or harmful compounds from air or water, or we are addressing the recovery of some organic (dyes, polymers, proteins) or inorganic (oxides, heavy metal ions) substances determining for success of the chosen process the are the type and performance of the membranes $[9,10]$.

Using composite membranes complex processes were performed: colloidal ultrafiltration [11], pervaporation [12], pertraction [13], electrodialysis [14], and liquid membranes [15], which were evaluated in terms of process performance using as target substances nitrophenols [16].

The results obtained for the removal and separation of nitrophenols are promising because the composite membranes have demonstrated high selectivity and outstanding fluxes $[17,18]$.

The process that focused attention through directed selectivity brought to the separation is pertraction (fig. 1), which combines the different mediated permeation velocity of the chemical species in the receiving phase through the membrane, with selective extraction by means a chemical reaction in the receiving phase (acceptor).

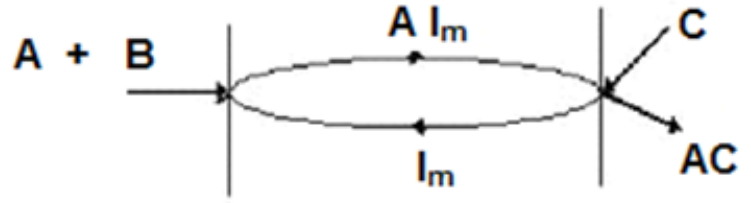

Source Phase

Membrane

Recixing Phase

Fig. 1. Separation conducted by pertraction: A-chemical species of interest, B-competitive chemical species, C- specific reagent for the chemical species $A, I_{m}$ - Membrane ionophore, AC-useful compound

The pertraction is a membrane process of great interest both because selectivity can be imposed through the membrane ionophore (Im) or chemical species C, and because this substance $(C)$, if properly chosen, can result in a practical utility $\mathrm{AC}$ compound, so the separation becomes recovering $[19,20]$.

In the previous study, it was shown, for the case of nitrophenols that by suitable coupling, esterification or etherification reactions can be obtained by percolation: dyes, medicaments, antidepressants [21].

In the present paper, the recuperative separation of aluminum ion from the aluminum sulfate-treated water through permeation using composite membranes, followed by the reaction of complexation with 8-hydroxy quinoline is approached.

\section{Experimental part}

Materials and methods

Materials and aparatus

$\mathrm{Al}_{2}\left(\mathrm{SO}_{4}\right)_{3} \cdot \mathrm{H}_{2} \mathrm{O}, \mathrm{MgSO}^{\prime} \mathrm{CaSO}_{4}$, and 8-hydroxyquinoline, Sigma Aldrich, standard buffer solutions ( $\mathrm{pH}=1.68 ; 4.01$; 7.00; 10.01) from EUTECH Instruments.

\footnotetext{
*email: andra3005@yahoo.com; GhNechifor@gmail.com
} 
Capillary polypropylene / ethylene propylene diene terpolymer sulfonic acid (PP / S-EPDM) composite membranes were obtained by capillary membrane (PP) impregnation with ionophore (S-EPDM) [21, 22].

The membrane module has a total area of $1 \mathrm{~m}^{2}[10,21]$, phase recirculation (source and receiving) being made with peristaltic pumps.

Ultra pure water was obtained with a Millipore system.

The analyses were performed with a UV-VIS CAMSPEC spectrometer and respectively an atomic flame emission spectrometer PHLAFO 4. Atomic Adsorption Spectrometer Apparatus PerkinElmer AAnalyst 400 for the analysis validation.

\section{Procedures}

\section{Solution preparation}

The source phase (SP), represented by synthetic aqueous solution that simulates a water that has been treated with aluminium sulphate, was achieved by dissolving equimolar amounts of $\mathrm{Al}_{2}\left(\mathrm{SO}_{4}\right)_{3}(342.131 \mathrm{~g} /$ $\mathrm{mol}), \mathrm{MgSO}_{4}(120.361 \mathrm{~g} / \mathrm{mol})$ and ${ }^{2} \mathrm{CaSO}_{4}(136.134 \mathrm{~g} /$ $\mathrm{mol}$ ) in the pure water so that the concentration of each is at the solubility limit of the heaviest soluble sulphate, calcium sulphate, cca. $0.3 \%$. The stock solution is $10^{-3} \mathrm{~mol}$ $/ L(M)$ for each of the three cations studied.

Reciving phase (RP), 8-hydroxyquinoline (HQx) $\left(145.161 \mathrm{~g} / \mathrm{mol}, \mathrm{pKa}_{1}=5.017 ; \mathrm{pKa}_{2}=9.812\right)$ solution was obtained by contacting the solid substance at $25^{\circ} \mathrm{C}$ in ultrapure water or standard buffer solutions, a saturated solution (less than $1 \mathrm{mg} / \mathrm{mL}$ ) being obtained.

\section{Permeation through membrane}

The installation used for studying the permeation process provides a usable surface area of $1 \mathrm{~m}^{2}$ [21], the source phase solution volume is $3 \mathrm{~L}$, and the receiving phase is $300 \mathrm{~mL}$.

The two phases are recirculated through the outer membranes (SP) and membranes (RP), respectively, by means of individual peristaltic pumps that can provide flow variations between 2 and $200 \mathrm{~mL} /$ min by varying the intensity of the power supply.

Samples for analysis are taken at pre-established time intervals using $1 \mathrm{~mL}$ syringes and analyzed using UV-Vis CAMSPEC spectrometer (for the receiving phase) and for result validation at atomic absorption spectrometer (AAS PerkinElmer).
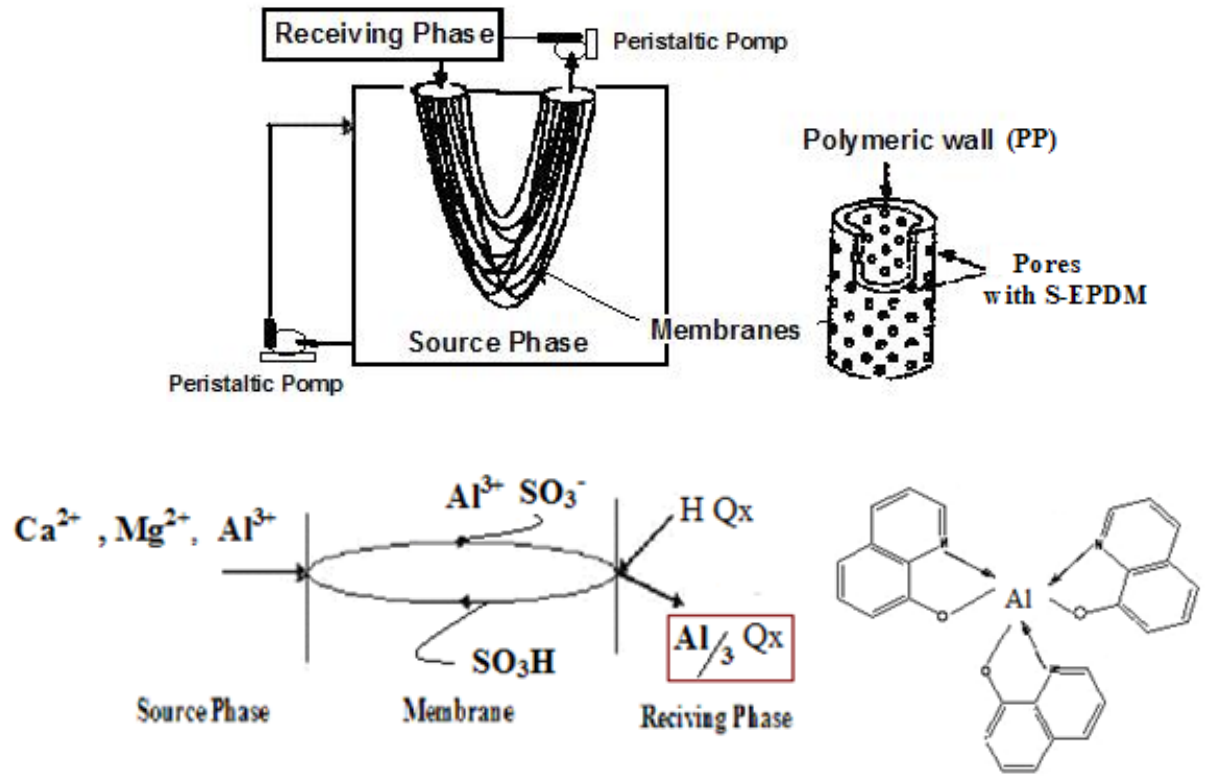

Fig. 2. The permeation installation

Fig. 3. Separation by directed pertraction: (a) $\mathrm{Al}^{3+}$ - chemical species of interest; $\mathrm{Ca}^{2+}, \mathrm{Mg}^{2+}$ - competing chemical species; HQx- specific reagent for the chemical species $\mathrm{Al}^{3+}$, $-\mathrm{SO} 3 \mathrm{H}$ membrane ionophore, $\mathrm{Al}_{3} \mathrm{Qx}$ - useful compound; (b) useful compound structure 
hydroxyquinoline, in order to obtain a useful compound by separating the aluminum through the PP / S-EPDM membrane (fig. 3).

Determining the optimal flow rate of the receiving phase

In order to determine the optimal flow rate for the receiving phase, source solution having a 10 times higher volume, was recirculated at a constant flow rate of 100 $\mathrm{mL} / \mathrm{m}^{2} \mathrm{~min}$ and maintained at $\mathrm{pH} 4$.

The receiving phase $\left(\mathbf{Q}_{\mathrm{RP}}\right)$ is variated between 5 and 25 $\mathrm{L} / \mathrm{m}^{2} \mathrm{~min}$ at $\mathrm{pH}=4$ and $7 \mathrm{in}$ the receiving phase. Operating time is kept constant, $5 \mathrm{~h}$, for each working flow rate.

The aluminum ion flow (FIF) through the membrane increases with the increase of the receiving phase flow over the entire operating range (fig. 4a), while the recovery factor (RF) rises in the range $5-15 \mathrm{~L} / \mathrm{m}^{2} \mathrm{~min}$, after which a stagnation in observed (fig. 4b).

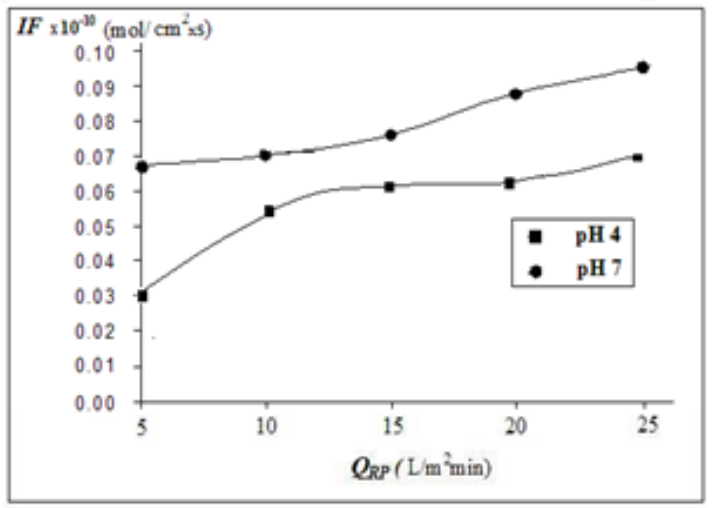

$a$

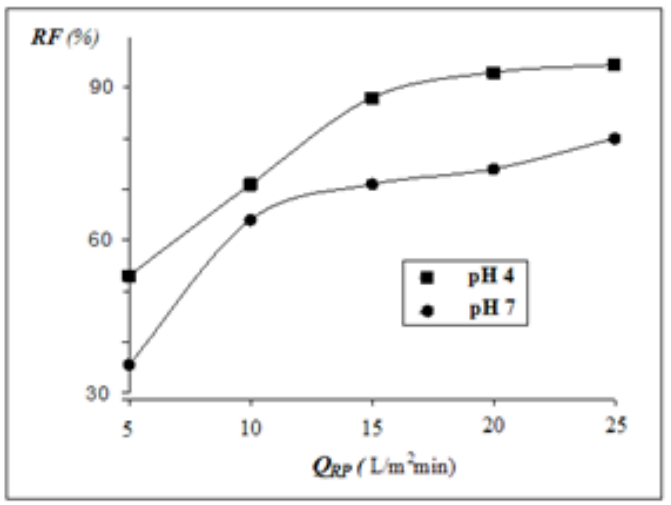

$b$

Fig. 4. Variation of aluminum pertraction performance parameters depending on recirculation flow of receiving phase: $a$ - ion flow (IF) and $b$ - recovery factor (RF)

The flow rate of the receiving phase is chosen at minimum $20 \mathrm{~L} / \mathrm{m}^{2} \mathrm{~min}$ for all subsequent experiments to ensure a relatively high ion flow, but also for the recovery factor to enter the corresponding field (fig. 4b).

However, increasing the flow rate of the receiving phase over $25 \mathrm{~L} / \mathrm{m}^{2} \mathrm{~min}$ is not recommended because of the secondary foaming phenomena appearance, and also due to the increase in energy consumption.

\section{Determination of $\mathrm{pH}$ and optimal working time}

In order to determine the $\mathrm{pH}$ and optimum working time, the source phase $\left(\mathrm{Al}^{3+} 10^{-3} \mathrm{M} ; \mathrm{Mg}^{2+} 10^{-2} \mathrm{M} ; \mathrm{Ca}^{2+} 10^{-3} \mathrm{M}\right)$ with $\mathrm{pH}=4$ (where all ions are free in solution), is contacted one at a time with receiving phase having $\mathrm{pH}=4.01 ; 7.00$ and 10.01, saturated in 8 hydroxyquinoline.

Figure 5 shows the significant differences in the concentration of aluminum and magnesium ions in the source phase during operation at the three $\mathrm{pH}$ values of the receiving phase (fig. 5).
At $p \mathrm{H}=4$ of the receiving phase, the aluminum concentration in the source phase decreases steeply in the first 180 min of operation, while the magnesium ion concentration decreases slowly, insignificantly (fig. 5a).

After an operating time of about 240 min the ion concentration remains quasi- constant. Increasing the $\mathrm{pH}$ of the receiving phase at 7 leads to a continuous downward variation of source phase concentration for about 180 minutes for both ions, but with a steeper slope for the aluminum ions (fig. 5b).

Interestingly is that at $\mathrm{pH}=10$, the two studied ions have a similar decrease in concentration in the source phase (fig. $5 \mathrm{c}$ ) over the entire time interval studied.

The results obtained impose for an adequate phase separation of aluminum ion a $\mathrm{pH}=4$ for the receiving phase and an operating time of maximum $240 \mathrm{~min}$.

At higher $\mathrm{pH}$ values in the receiving phase ( 7 and 10$)$ is noted a competition between the two ions, which are transferred simultaneously through the membrane.

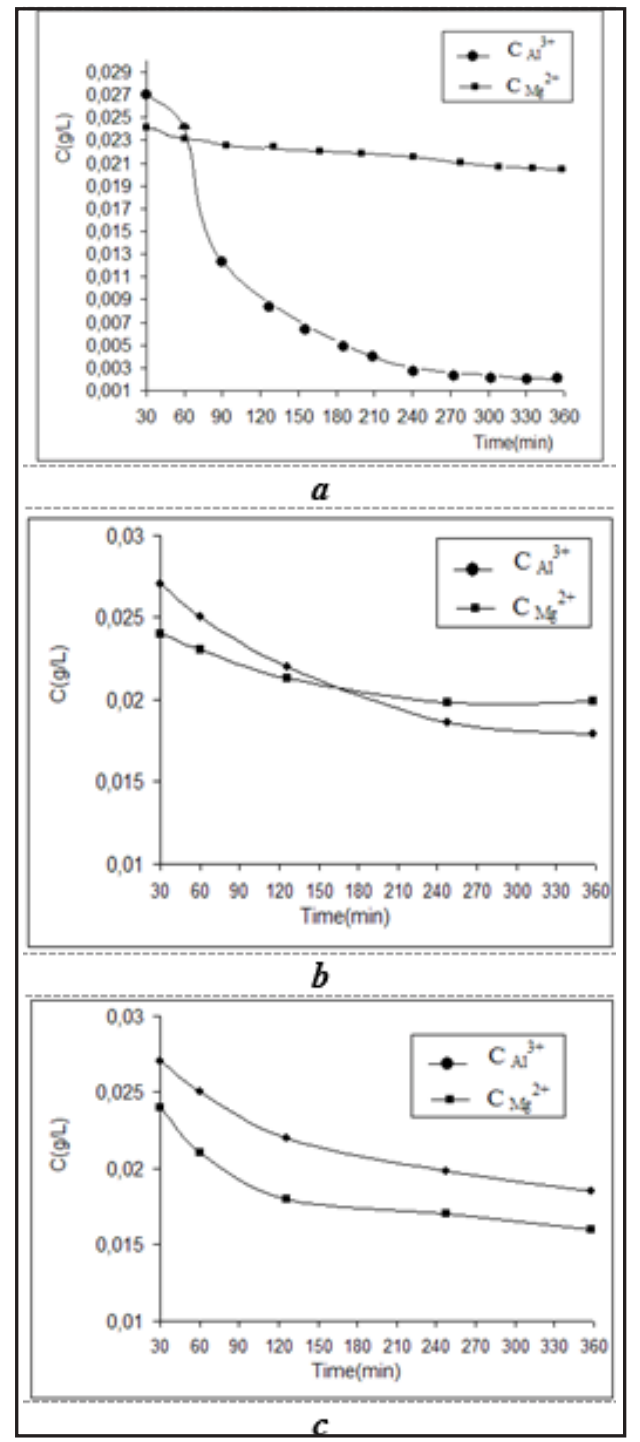

Fig. 5. Variation of aluminum and magnesium ion concentration in the source phase depending on the operating time and $\mathrm{pH}$ of the receiving phase: a) $\mathrm{pH}=4$; b) $\mathrm{pH}=7$; c) $\mathrm{pH}=10$

Experimental observations are in agreementwith with the mode in which the two ions form complexes with 8hydroxyquinoline: aluminum ion at $\mathrm{pH}=4$, and magnesium ion at $\mathrm{pH}$ greater than 9 [31].

In this $\mathrm{pH}$ range, the solubility of oxine in pure water is imposed by the ionization through the reaction with water molecules, relations (4) and (5) [31,32]: 


$$
\begin{aligned}
& \mathrm{H}_{2} \mathrm{Qx}^{+}+\mathrm{HOH} \rightleftarrows \mathrm{HQx}+\mathrm{H}_{3} \mathrm{O}^{+} ; \mathrm{K}_{\mathrm{al}} \\
& \mathrm{HQx}+\mathrm{HOH} \rightleftarrows \mathrm{Qx}^{-}+\mathrm{H}_{3} \mathrm{O}^{+} ; \mathrm{K}_{\mathrm{a} 2}
\end{aligned}
$$

Each ionization equilibrium is characterized by the corresponding acidity constants, the relationships (6) and (7) $[32,33]$ :

$$
\begin{gathered}
K_{a 1}=\frac{[\mathrm{HQx}]\left[\mathrm{H}_{3} \mathrm{O}^{+}\right]}{\left[\mathrm{H}_{2} \mathrm{Qx}^{+}\right]} \\
K_{a 2}=\frac{\left[\mathrm{Qx}^{-}\right]\left[\mathrm{H}_{3} \mathrm{O}^{+}\right]}{[\mathrm{HQx}]}
\end{gathered}
$$

Formulas (4-7) allow the calculation of 8-hydroxyquinoline concentration in acid and conjugated base form at equilibrium depending on the solution $\mathrm{pH}$, the relationship (8-11).

$$
\mathrm{C}_{0}=\left[\mathrm{H}_{2} \mathrm{Qx}^{+}\right]+[\mathrm{H} \mathrm{Qx}]+\left[\mathrm{Qx}^{-}\right]
$$

Taking into account the total concentration of dissolved acid and the $\mathrm{Ka}_{1}$ and $\mathrm{Ka}$ acid constants of $\mathrm{HQx}$, the equilibrium concentrations of the $\mathrm{H}_{2} \mathrm{Qx}+, \mathrm{HQx}$ and $\mathrm{Qx}$ species can be deduced, depending on the concentration of hydrogen ions, respectively, depending on $\mathrm{pH}$, equations (9-11).

$$
\begin{aligned}
& {\left[\mathrm{H}_{2} \mathrm{Qx}^{+}\right]=C_{0}\left(1+\frac{K_{a 1}}{\left[\mathrm{H}_{3} \mathrm{O}^{+}\right]}+\frac{K_{a 1} K_{a 2}}{\left[\mathrm{H}_{3} \mathrm{O}^{+}\right]}\right)^{-1}} \\
& {[\mathrm{HQx}]=C_{0}\left(1+\frac{\left[\mathrm{H}_{3} \mathrm{O}^{+}\right]}{K_{a 1}}+\frac{K_{a 2}}{\left[\mathrm{H}_{3} \mathrm{O}^{+}\right]}\right)^{-1}} \\
& {\left[\mathrm{Qx}^{-}\right]=C_{0}\left(1+\frac{\left[\mathrm{H}_{3} \mathrm{O}^{+}\right]}{K_{a 1}}+\frac{\left[\mathrm{H}_{3} \mathrm{O}^{+}\right]}{K_{a 1} K_{a 2}}\right)^{-1}}
\end{aligned}
$$

Correlating concentrations suggested by the relationships (4-11) with the constants for studied ions complexes formation with 8-hydroxyquinoline [31,34] it can be illustrated which ions will be separated depending on the $\mathrm{pH}$ of the receiving phase (fig. 6).

The results of ion transport (fig. 5) correlate with the theoretical information suggested in the diagram from figure 6 , justifying the variation in the concentration of the aluminium and magnesium ions depending on the $\mathrm{pH}$ of the receiving phase.

It must be emphasized that at high $\mathrm{pH}$ values a competition exists between the formation of 8hydroxyquinoline complexes and the corresponding hydroxyls due to the increase in the hydroxyl ions concentration. It was found (fig. 7) that at $\mathrm{pH} 10$ in the receiving phase there is a slight variation in the concentration of calcium ion in the source phase which can be justified by immobilizing this ion as calcium hydroxide in the receiving phase.

Ion permeation was studied at the $\mathrm{pH}$ of the membrane system phases (fig. 3) greater than 2, so that the S-EPDM sulfonic groups are ionized.

The following optimal parameters have been established for the separation of aluminum ions from an aqueous solution containing equimolar amounts of magnesium and calcium ions:

- membrane module with a usable area of $1 \mathrm{~m}^{2}$;

- capillary composite membranes with sulphonic ionizing groups (S-EPDM/PP);

- source phase $\mathrm{pH}, 4$;

- receiving phase $\mathrm{pH}, 4$;

- the constant flow of the source phase (through the capillary membrane fascicle), $100 \mathrm{~L} / \mathrm{m}^{2} \mathrm{~min}$

- receiving phase flow (through the capillary membrane), over $20 \mathrm{~L} / \mathrm{m}^{2} \mathrm{~min}$;

\begin{tabular}{|c|c|c|c|c|c|}
\hline \multicolumn{3}{|c|}{$\left[\mathrm{H}_{2} \mathrm{Qx}^{+}\right]=[\mathrm{H} \mathrm{Qx}]$} & \multicolumn{2}{|c|}{$\left[\mathrm{H}\right.$ Qx] $=\left[\mathrm{Qx}^{-}\right]$} & \\
\hline $\mathrm{Al}^{3+}$ & & $\mathrm{Mg}^{2+}, \mathrm{Al}^{3+}$ & 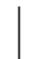 & $\mathrm{Mg}^{2+}, \mathrm{Al}^{3+}$ & \\
\hline & 5.0 & & 9.8 & $\mathrm{Ca}^{2+}$ & $\mathrm{pH}$ \\
\hline $\mathrm{H}_{2} \mathrm{Qx}^{+}$ & & H Qx & & $\mathrm{Qx}^{-}$ & \\
\hline
\end{tabular}

- receiving solution saturated in 8-hydroxyquinoline at $\mathrm{pH}=4$;

- operation time: over $180 \mathrm{~min}$.

In the presented conditions, an ionic flux (IR) above $10^{-11} \mathrm{~mol} / \mathrm{cm}^{2} \mathrm{~s}$ and a recovery factor of over $90 \%$ is obtained. Aluminum is recovered under thr form of a complex with 8-hydroxyquinoline.

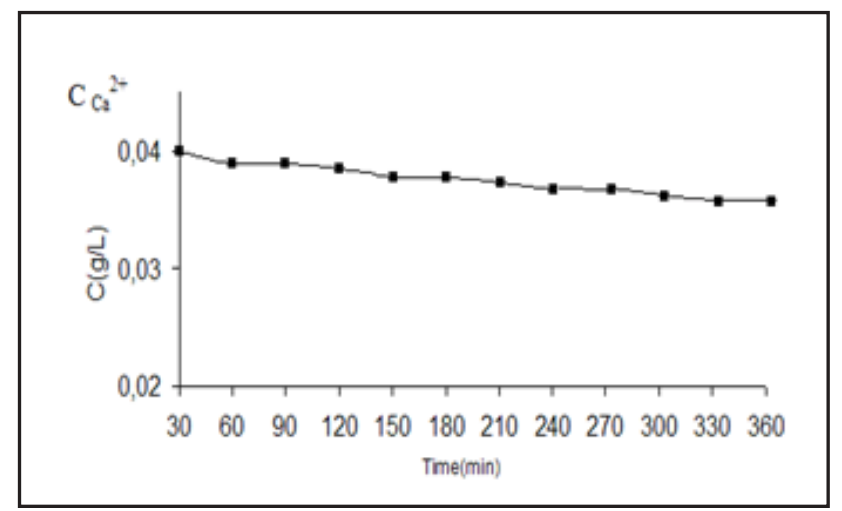

Fig. 6. Diagram of the 8-hydroxyquinoline speciation, based on $\mathrm{pH}$, correlated with the ions that are separated according to the receiving $\mathrm{pH}$ phase
Fig. 7. Variation of calcium ion concentration in the source phase at $\mathrm{pH}=10$ in the receiving phase 


\section{Conclusions}

Approaching the recovery of aluminum ion from aluminum sulfate-treated water through permeation using polypropylene capillary composite membranes with ethylene propylene diene terpolymer sulfonic acid (PP / SEPDM) inclusions, followed by a complexation reaction with 8-hydroxyquinoline allow ed us to operate at an ionic flux (IR) of over $10^{-11} \mathrm{~mol} / \mathrm{cm}^{2}$. $\mathrm{s}$ and a recovery factor (RF) of over $90 \%$.

\section{References}

1.Van der BRUGGEN, B., DAEMS, B., WILMS, D., VANDECASTEELE, C., Sep. Purif. Technol., 22-23, 2001, p. 519.

2.LEE, S.Y., KIM, B.N., HAN, J.H., CHANG, S.T., CHOI, Y.W., KIM, Y. H., MIN, J., J. Hazard. Mat., 182, 2010, p. 936.

3.TERESA, A., REIS, M., ONDINA DE FREITAS, M.F., ISMAEL, M.R.C., CARVALHO, J.M.R., J. Membr. Sci., 305, 2007, p. 313.

4.SZEP, R., MATEESCU, E., NECHIFOR, A. C., KERESZTESI, Á., Environ.

Sci. Pollut. Res., 24, no. 35, 2017, p. 27288.

5.ILIE, M., MARINESCU, F., SZEP, R., GHITA, G., DEAK, GY., ANGHEL, A.M., PETRESCU, A., URITESCU, B., Carpath. J. Earth. Env., 12, no. 2, 2017, p. 437.

6.SZEP, R., KERESZTES, R., KORODI, A., TONK, SZ.,NICULAE, A.G., BIRLOIU, A.M., Rev. Chim.(Bucharest), 67, no. 10, 2016, p. 1914.

7.NECHIFOR, G., ALBU, B.G., RATA, D., POPESCU, G., Rev. Chim. (Bucharest), 47, no. 3, 1996, p. 260.

8.GHIMPUSAN, M., NECHIFOR, G., DIN, I.S., NECHIFOR, A.C., PASSERI, P., Mat. Plast., 53, no.4, 2016, p. 578.

9.RIKABI, A.A.K.K., BALABAN (CHELU), M., HARABOR, I., ALBU, P.C., SEGARCEANU, M., NECHIFOR, G., Rev. Chim. (Bucharest), 67, no. 9, 2016, p. 1658.

10.GHIMPUSAN, M., NECHIFOR, G., NECHIFOR, A.C., DIMA, S.O., PASSERI, P., J ournal of Environmental Management, 203, 2017, p. 811. 11.RIKABI, A.A.K.K., NECHIFOR, A.C., MOHAMMED, T. J., OPREA, O., MIRON, A.R., SEGARCEANU, M., VAIREANU, D.I., Rev. Chim. (Bucharest), 67, no. 8, 2016, p. 1489.

12.COROBEA, C., DONESCU, D., RADITOIU, V., VOICU, S.I., NECHIFOR, G., Rev. Chim. (Bucharest), 57, no. 9, 2006, p. 981.

13.AL ANI, H.N.A., CIMBRU, A.M., TANCZOS, S.K.., DIN, I.S., CUCIUREANU, A., NAFLIU, I.M., NECHIFOR, G., Rev. Chim. (Bucharest), 68, no. 3, 2017, p. 427.

14.SEGARCEANU, M., MIRON, A.R., TANCZOS, S.K., RIKABI, A.A.K.K., NAFLIU, I.M., VAIREANU, D.I., Mat. Plast, 55, no.2, 2018, p. 137. 15.ZAHARIA, I., DIACONU, I., RUSE, E., NECHIFOR, G., Dig. J. of Nanomater. Bios., 7, no. 3, 2012, p. 1303.
16.RIKABI, A.A.K.K., CUCIUREANU, A., CHELU, M., MIRON, A.R., ORBECI, C., POPA, A.G., CRACIUN, M.E., Rev. Chim. (Bucharest), 66, no. 8, 2015, p. 1093.

17.DIN, I.S., CIMBRU, A.M., ANI, H.N.A.A., NAFLIU, I.M., TANCZOS, S.K., NECHIFOR, G., Rev. Chim. (Bucharest), 69, no. 5, 2018, p. 1084. 18.DIN, I.S., CIMBRU, A.M., RIKABI, A.A.K.K., TANCZOS, S.K., COTORCEA, S.T., NECHIFOR, G., Rev. Chim. (Bucharest), 69, no. 7, 2018, p. 1603.

19.AL ANI, H.N.A., CIMBRU, A.M., TRISCA-RUSU, C., TANCZOS, S.K.., CUCIUREANU, A., NECHIFOR, A.C., Rev. Chim. (Bucharest), 68, no. 2, 2017, p. 203.

20.AL ANI, H.N.A., CIMBRU, A.M., DIN, I.S., TANCZOS, S.K., NAFLIU, I.M., CUCIUREANU, A., Mat. Plast., 54, no. 2., 2017, p. 353.

21.NAFLIU, I.M., AL ANI, H.N.A., GROSU (MIRON), A.R., TANCZOS, S.K., MAIOR, I., NECHIFOR, A.C., Mat. Plast., 55, no. 4, 2018, p. 511 22.MAKOWSKI, H.S., O'FARRELL, C.P., US Patent 4,131,586, 1978

23.SZEP, R., BODOR, Z., MIKLOSSY, I., NITA, I.A., OPREA, O.A., KERESZTESI, A., Sci. Total Environ., 647, 2019, p. 275.

24.KERESZTESI, A., PETRES, S., GHITA, G., DUMITRU, F.D., MONCEA, M.A., OZUNU, A., SZÉP, R., Rev. Chim. (Bucharest), 69, no.1, 2018, p. 57. 25.SZEP, R., MATEESCU, E., NITA, A., BIRSAN, M., BODOR, Z., KERESZTESI, A., Atmos. Res., 214, 2018, p. 311. doi:10.1016/ j.atmosres.2018.08.009

26.BUNGAU, S., TIT, D.M., FODOR, K., CIOCA, G., AGOP, M., IOVAN, C., CSEPPENTO, D.C., BUMBU, A., BUSTEA, C., Sustainability, 2018, 10, 2788. doi:10.3390/su10082788

27.LEE, A., ELAM, J.W., DARLING, S.B., Environmental Science Water Research \& Technology, 2, 2016, p. 17

28.JIANG, ZHEN-MAO, LI, AI-MIN, CAI, JIAN-GUO, WANG, CHUN, ZHANG, QUAN-XIN, J ournal of Environmental Sciences, 19, 2007, p. 135.

29.BALASUBRAMANIAN, A., VENKATESAN, S., Pol. J. Chem. Tech., 14, 2012, p.46

30.ABBAS, R.A., JARAD, A.J., NAFLIU, I.M., NECHIFOR, A.C., Rev. Chim.(Bucharest), 70, no. 1, 2019, p. 36

31.LUCA, C., DUCA, AL., CRISAN , I. AL., Chimie analitica si analiza instrumentala, Editura Didactica si Pedagogica, Bucuresti, 1983

32.SHAR, G.A., SOOMRO, G.A., J. Chem. Soc. Pak., 27, no.5, 2005, p.471.

33.BOSCH, M.E., SANCHEZ, A.J.R., ROJAS, F.S., OJ EDA, C.B., J. Pharm. Biomed. Anal., 44, no. 4, 2007, p. 831.

34.AHMED, W., KHAN, S.A., MUNAWAR, K.S., KHALID, A., KAWANL, S., Tropical. J. Pharm. Res., 16, no.5, 2017, p. 1137

Manuscript received: 18.03 .2019 